\title{
Intimate partner violence: $A$ helpful guide to legal and psychosocial support services
}

\author{
C Lopes, BA Hons (Psychology) \\ Heinrich Böll Foundation Southern Africa, Cape Town, South Africa
}

Corresponding author: C Lopes (claudia.lopes@za.boell.org)

\begin{abstract}
Violence against women is a significant problem that profoundly affects the physical and mental wellbeing of those affected. While medicolegal interventions in South Africa have been firmly established to respond to sexual offences, no formal protocols on intimate partner violence interventions at primary healthcare level are in place yet. In support of recent policy recommendations for the development of a combined health and social sector system response to intimate partner violence, this article provides health professionals with insight into domestic violence and current legal and psychosocial support services. It focuses on how to support and advise abused women about practicalities of obtaining protection orders and accessing shelter services.
\end{abstract}

S Afr Med J 2016;106(10):966-968. DOI:10.7196/SAMJ.2016.v106i10.11409

Underreporting of sexual and domestic violence (DV) offences and problematic police recording of DV cases in particular are barriers to fully understanding the scale of violence against women. However, the available evidence paints a grim picture: police crime statistics between 2007 and 2013 (2013 being the final year of gender disaggregated data) reveal 1016588 cases of contact crimes committed against women. ${ }^{[1]}$ Femicide is a major contributing factor, as $50.3 \%$ of female homicides in South Africa (SA) are committed by intimate partners. ${ }^{[2]}$

The impact of intimate partner violence (IPV) is considerable. Yet, provincial studies found that in a sample of 216 women accessing shelters for IPV, only one had been referred by a medical professional. ${ }^{[3,4]}$ Given our excessive rates of IPV, with concomitant multiple adverse health and developmental consequences for women and their children, medical personnel should take IPV more seriously. While IPV occurs in all forms of sexual relationships, and involves any gender, statistically men are the greatest perpetrators of IPV. This article therefore makes overall reference to IPV against women.

\section{Understanding IPV}

Commonly, women remain in abusive relationships for many years, suffering a multitude of devastating, life-altering consequences. ${ }^{[5]}$ These women are often harshly judged for 'choosing' to stay in or for not reporting an abusive relationship. This secondary victimisation reveals a lack of insight into IPV and how it effects the psyche of an abused woman.

IPV entails different patterns of behaviour with the intention to exert power and control over an intimate partner. Most easily recognised are injuries sustained from being physically assaulted. However, some perpetrators inflict injuries that are not visible. Victims may also mask such injuries by wearing less revealing clothes or by denying or excusing injuries sustained. Downplaying or justifying the occurrence of abuse is closely associated with experiencing emotional and psychological abuse. Perpetrators commonly accuse victims of provoking the abuse, constantly reinforcing why the abuse is 'justified', which leads victims to believe they deserve the punishment. This psychologically abusive strategy is compounded by negative comments, swearing, insults, criticism and humiliation in public, all of which further erode the victim's sense of self-worth. This reinforces her insecurity and subservience to the perpetrator's greater power.

Another technique abusers commonly employ to control and manipulate their partner is to isolate her from family, friends and other support networks. Combined with limiting her access to resources by withholding her wages or preventing her from obtaining a job (economic abuse), this isolation traps her further. Forced sexual intimacy is a pervasive form of IPV, yet usually overlooked (ignored) owing to cultural beliefs of male marital ownership. Indeed, girls nationwide are socialised by their mothers to expect marriage to entail such difficulties.

An additional, rather confusing factor is that she may still love the abuser. The deterioration of an abusive relationship is often gradual, characterised by cyclical periods of 'normalcy' ('honeymoon phase'), tension building and bouts of violence that escalate in severity over time. ${ }^{[5]}$ During the honeymoon phase, the perpetrator is loving and apologetic, promising that the violence will never happen again. This is seldom the case. Soon tension starts to build as the perpetrator finds fault to justify further violence. Similarly, a victim may fluctuate between loving and hating her partner.

The presence of children is often a decisive factor for not leaving an abusive partner. The abuser may emotionally blackmail the victim by threatening that should she leave, her children will be removed from her care. She may also believe that it is in her children's best interest to live with both parents (a false, but frequently socially reinforced perception).

Reasons for remaining in abusive relationships equally affect disclosure of abuse. This is often associated with guilt regarding disloyalty to the abuser and/or feeling ashamed and humiliated by the abuse. Many women are too frightened to leave or report the abuse in case of further victimisation, i.e. losing her children, becoming destitute, or that she may not be believed or supported.

\section{Effective responses to IPV: Support and advice}

Effective health system responses include acknowledging IPV and that it is unacceptable. ${ }^{[6]}$ This is particularly imperative in SA, where multiple forms of violence are seen as normative. Understanding the complexity of IPV is key to establishing a caring, empathetic and non-judgemental response. If you suspect abuse, the following are some suggested approaches:

- Ensure that it is safe to talk to the victim, with minimal interruptions. She should preferably be on her own.

- Starting the conversation may be difficult, but you may gently explore what it is that you have noticed that causes you concern. 
- Importantly, she should know that the conversation will be confidential and therefore not shared with her partner or anyone close to her. Inform her, however, that you will record the information in her medical record, as she may need evidence of abuse in future.

- Gently explain that your intention is to help her. Be open to the possibility that she may deny abuse or not want to confide in you. If so, assure her that she can return to you should she feel differently.

If the victim is open to discussing the situation:

- Acknowledge that she is not alone as other women have been/are in similar circumstances.

- Acknowledge possible feelings of fear, embarrassment, guilt and/or shame.

- Do not ask her what she did to have caused the abuse. Nothing done or said can justify abusers' behaviour.

- Only make promises that you can keep.

- Encourage and support her to make her own decisions. Do not tell her to leave the relationship. It is her choice.

- Do not do anything that will make her uncomfortable or that she is not ready for, and certainly do not put either of you in harm's way by offering to talk to the abuser.

Lastly, assist by exploring available options with her. If she, for example, prefers to remain in the relationship but wants the abuse to stop, advise how she can apply for a protection order. If she wishes to leave the relationship, enquire about how she will support herself and/or whether she can stay with family and/or friends who could emotionally support her. If neither of these options is feasible, assist her with accessing a shelter for abused women. The next section discusses both these interventions.

\section{Legal recourses available to victims:}

\section{Applying for a protection order}

The Domestic Violence Act (DVA) No. 116 of $1998^{[7]}$ provides protection to those directly affected by DV. While this article focuses on DV within intimate relationships (past, present or perceived), it also occurs in other domestic relationships such as members of a family or people sharing a living space. The DVA enables victims (complainants) to apply for a protection order against perpetrators of abuse (respondents). Family members are also eligible for protection if they are directly affected by the abuse. In addition to the types of abuse referred to above, the DVA lists intimidation, harassment, stalking, damage to property, and entry into a victim's residence.

To apply for a protection order, complainants present at the magistrate court nearest to their home or work during court hours. In an emergency outside court hours, the complainant must present at their closest police station and explain how she will suffer undue harm if not urgently assisted. A third party may apply on behalf of a complainant if same has given written consent to do so. Written consent is not required if the complainant is $<18$ years of age, mentally disabled, or in situations where the court is satisfied that the complainant was unable to provide consent.

At court, the application process is as follows:

- The complainant completes Form 2, which is available from the court clerk.

- This clerk has a duty to inform applicants about the DVA and to assist with the completion of application forms. In some courts, non-profit organisations are available to assist complainants with completing the form. ${ }^{[8]}$

- The form requests information such as the complainant's and respondent's contact details; abuse suffered; use of weapons; reasons why the application should be granted; and types of protection required.
- Supporting documents, such as photographs of damage to person and/or property, police reports, a health professional's letter, Form J88 and/or affidavits by witnesses, will strengthen the application.

- Once completed, the clerk submits the form to the magistrate, who decides whether to grant an interim protection order.

- If an interim order is granted, it only comes into force once served on the respondent (generally by police). It is issued with a notice for the respondent to appear on a date set by the court (return date).

- On the return date, the respondent can argue his/her case at a hearing presided over by the magistrate. Based on the evidence presented, the magistrate decides whether to grant a final protection order.

- A warrant of arrest is attached to any order (interim or final) granted. This enables the police to arrest the perpetrator if $s /$ he fails to adhere to the terms set out in the order.

In granting an order the court can (among any other action it deems fit):

- prohibit the respondent from committing or enlisting other's help to commit any act of IPV

- prohibit the respondent from entering the complainant's home or shared residence (or part thereof), or prohibit the respondent from preventing the complainant entry into a shared residence

- prohibit the respondent from harassing the complainant at work

- seize any firearm or dangerous weapon in possession of the respondent

- order that the respondent pay rent and/or other forms of monetary relief

- refuse or allow only conditional contact with a child if the court deems it to be in the child's best interest.

Unfortunately, even though the DVA is progressive in nature, problems have been experienced with its implementation. Although it provides for an applicant to apply for an order during court operating hours, in practice it depends on the court's capacity (e.g. at Wynberg Magistrate's Court in Cape Town, applications are normally only accepted until mid-morning). While anyone who is affected by DV can apply for a protection order, foreign nationals have reported difficulties in doing so. In response to the latter example, Sanja Bornman, attorney in the Lawyers for Human Rights Gender Equality Programme, suggests that if anyone is being denied the service, they should challenge the service provider to produce proof that foreign nationals are excluded. ${ }^{[8]}$

Furthermore, police do not always respond as mandated by law. Sometimes, despite the presence of a protection order and a warrant of arrest, police opt to warn the perpetrator instead of arresting him. ${ }^{[9]}$ Elsewhere, officers stated that a protection order could only be applied for if a charge against the perpetrator had been laid. This is untrue. A victim has the right to lay a charge of abuse, but is not required to do so to be granted a protection order. ${ }^{[4]}$

In addition to requiring the police to act in cases of contravention of a protection order, both the DVA and the South African Police Services' National Instructions place a duty on police to assist victims of DV to obtain medical treatment, to collect personal items from their residence, and to find suitable shelter.

\section{Sheltering services for abused victims}

Shelters provide women and their children with respite from IPV - a safe space to gather their thoughts and feelings while planning for their future. The provision of shelter services in SA falls under the Victim Empowerment Programme of the Department of Social Development (DSD). DSD's Minimum Standards on Shelters specifies that shelters must meet the basic needs of women and their children (such as food, clothing and protection), as well as provide counselling, support and skills development. ${ }^{[10]}$ In practice, with sufficient funding, shelters can 
provide invaluable care and assistance to victims. This includes individual counselling, support groups and extramural activities. Among other psychosocial support provision, shelters help women to access healthcare and may assist with their legal needs, such as applying for protection orders, laying charges of abuse, instituting divorce proceedings, and applying for grants and legal documents such as birth certificates or identity documents. They may also assist women with finding employment. Most shelters provide on-site crèche facilities for young children. Older children may be assisted to relocate to schools closer to the shelter, or shelters may provide financial assistance for travel to and from their current school.

To refer a patient, the National Shelter Movement of SA, an umbrella body representing 78 shelters across the country, advises that you have the following information at hand:

- their name, age, contact details, and contact information of next of kin (if appropriate)

- languages spoken (will a translator be needed?)

- level of education (can she read and write?)

- area(s) in which she (and abuser) currently reside

- brief history of abuse and most recent episode

- history of any psychiatric and/or substance abuse disorders, disabilities or chronic illness(es)

- citizenship status (SA or foreign?) ${ }^{[8]}$

- gender and ages of children, including whether she is pregnant.

Note that shelters' admission criteria differ and some:

- may not take children above a certain age (particularly boys)

- are unable to care for those with untreated psychiatric or substance abuse conditions

- may not have facilities to accommodate persons with disabilities

- require a referral letter and/or protection order before admittance.

While length of stay varies, most shelters offer 3 - 5 months' accommodation. Although some charge a minimal service fee if a woman is employed, the majority cover the costs of her stay for free. To find a suitable shelter in your province, please contact the relevant provincial shelter representative (Table 1).

\section{Conclusion}

Considering the physical and psychological impact of IPV, including its interrelationship with HIV transmission and teenage pregnancies, it is likely that women and girls will access healthcare prior to seeking intervention from the police or courts. Although attempts have been made to introduce IPV

Table 1. Executive and provincial representatives of the National Shelter Movement of South Africa, 2016

\begin{tabular}{|c|c|c|c|}
\hline $\begin{array}{l}\text { Provincial } \\
\text { representatives }\end{array}$ & Province & $\begin{array}{l}\text { Telephone } \\
\text { number }\end{array}$ & Email address \\
\hline $\begin{array}{l}\text { Zubeda Dangor: } \\
\text { executive head }\end{array}$ & Gauteng & $\begin{array}{l}0118545804 \\
0832898818\end{array}$ & zubeda@nisaa.org.za \\
\hline $\begin{array}{l}\text { Joy Lange: } \\
\text { executive member } \\
\text { and provincial } \\
\text { representative }\end{array}$ & Western Cape & $\begin{array}{l}0214486792 \\
0719063949\end{array}$ & joy@stanneshomes.org.za \\
\hline $\begin{array}{l}\text { Fisani Mahlangu: } \\
\text { executive member } \\
\text { and provincial } \\
\text { representative }\end{array}$ & Mpumalanga & $\begin{array}{l}0132432732 \\
0793109633\end{array}$ & $\begin{array}{l}\text { mburgvictimsupport@telkomsa.net } \\
\text { mahlangufisani@yahoo.com }\end{array}$ \\
\hline Sabera Timol & KwaZulu-Natal & $\begin{array}{l}0312076483 \\
0724463337\end{array}$ & krc@telkomsa.net \\
\hline Sarah Lekale & Free State & $\begin{array}{l}0573532865 \\
0721447171\end{array}$ & $\begin{array}{l}\text { lekalese@webmail.co.za } \\
\text { lekalese@gmail.com }\end{array}$ \\
\hline Rina van der Berg & North West & $\begin{array}{l}0145743476 \\
0723486526\end{array}$ & gracecentre@mweb.co.za \\
\hline $\begin{array}{l}\text { Nomawethu } \\
\text { Kunene }\end{array}$ & Gauteng & $\begin{array}{l}0114121940 \\
0116931945 \\
0719309734\end{array}$ & nomawethu.kunene@gmail.com \\
\hline Marihet Infintino & Gauteng & $\begin{array}{l}0118695856 \\
0824495210\end{array}$ & marihetinfo@amcare.org.za \\
\hline Rosaline Bailey & Northern Cape & $\begin{array}{l}0536314379 \\
0724443095\end{array}$ & ectc@telkomsa.net \\
\hline Mercy Cwayi & Eastern Cape & $\begin{array}{l}0422933985 \\
0726928392\end{array}$ & oneagleswings@telkomsa.net \\
\hline
\end{tabular}

screening guidelines for some health professionals, ${ }^{[11-13]}$ there is no formalised protocol on interventions at a primary healthcare level and training of healthcare providers is scanty. ${ }^{[5]}$ This is particularly problematic in a country notorious for some of the highest rates of violence against women globally. A recent policy brief recommends the development of a concerted holistic health and social development sector strategy to aid the identification and management of IPV cases. ${ }^{[13]}$ The adoption of such an initiative, combined with current legal and psychosocial support services available to victims, will go a long way to supporting abused women and their children and safeguarding their rights to be free from violence.

1. Watson J. The role of the state in addressing sexual violence Assessing police and health service delivery challenges faced by sexual offences victims. African Policing Civilian Oversight Policy Brief 2015(13).

2. Abrahams N, Mathews S, Jewkes R, Martin LJ, Lombard J. Every eight hours: Intimate femicide in South Africa 10 years later! South African Medical Research Council Research Brief. 2012. http://www.mrc.ac.za/policybriefs/everyeighthours.pdf (accessed 24 August 2016).

24 August 2016).
3. Bhana K, Vetten L, Makhunga L, Massawe D. Shelters Housing Women who have Experienced Abuse: Policy, Funding and Practice. Johannesburg: Tshwaranang Legal Advocacy Centre, 2012.

4. Bhana K, Lopes C, Massawe D. Shelters Housing Women who have Experienced Abuse: Policy, Funding and Practice. Profiling Three Shelters in the Western Cape. Cape Town: Heinrich Böll
Foundation and Tshwaranang Legal Advocacy Centre, 2012.

5. Watson J, Lopes C. Women Reach Out: A Reflection on Violence Against Women and Women's Stories of Hope. Cape Town: Rural Education, Awareness and Community Health, 2012.

6. Rees $\mathrm{K}$, Zweigenthal V, Joyner K. Health sector responses to intimate partner violence: A literature review. Afr J Primary Health Care Fam Med 2014;6(1). DOI:10.4102/phcfm.v6i1.712 7. Republic of South Africa. Domestic Violence Act 116, 1998 (Ac No. 116 of 1998). Government Gazette No. 19537:2. 1998. No. 116 of 1998). Government Gazette No. 19537:2. 1998 .
8. Gordon C. Intimate partner violence is everyones problem, but 8. Gordon C. Intimate partner violence is everyone's problem, but
how should we approach it in a clinical setting? S Afr Med J 2016;106(10):962-965. DOI:10.7196/SAMJ.2016.v106i10.11408

9. Lopes C, Massawe D, Mangwiro, M. Criminal Justice Responses: Assessing Implementation of the Domestic Violence Act in Gauteng. Cape Town: Heinrich Böll Foundation and Tshwaranan Legal Advocacy Centre to End Violence Against Women, 2013.

10. National Department of Social Development. Minimum standards on shelters for abused women. 2001. http://www.gov.za/sites/www. gov.za/files/shelter_0.pdf (accessed 24 August 2016).

11. Bateman C. 'Formulaic' gender-abuse guidelines seldom followed S Afr Med J 2012;102(6):343-345. DOI:10.7196/SAMJ.5965

12. Van Heyningen T, Myer L, Tomlinson M, Field S, Honikman S, Van Heyningen T, Myer L, Tomlinson M, Field S, Honikman S,
Preliminary Recommendations for Primary Level Screening of Preliminary Recommendations for Primary Level Screening of
Perinatal Populations for Depression, Anxiety and Suicidal IdePerinatal Populations for Depression, Anxiety and Suicidal Ide-
ation and Behaviour in South Africa. Perinatal Mental Health ation and Behaviour in South Africa. Perinatal Mental Health
Project, University of Cape Town. 2015. http://pmhp.za.org/ wp-content/uploads/Screening_Advisory_PMHP.pdf (accessed 6 September 2016)

13. Joyner K, Rees K, Honikman S. Intimate partner violence in South Africa: How to break the vicious cycle. Alan Flisher Centre for Public Mental Health, Policy brief, 2015. http://pmhp.za.org/wp-content/uploads/IPV_policybrief.pd (accessed 24 August 2016)

\section{Additional reading}

Fredericks J, Sanger C. A Simplified Guide to the Domestic Violence Act. Cape Town: Women's Legal Centre, 2014. http://www.wlce.co.za/ images/domesticviolenceguide.pdf (accessed 24 August 2016). Women's Aid. The Survivor's Handbook. Bristol: Women's Aid Federation of England, 2009. 